\title{
DIGITALISASI DAN DESKRIPSI NASKAH KUNO SEBAGAI UPAYA MEMPERKOKOH KEDAULATAN INDONESIA: STUDI KASUS NASKAH
}

\author{
AL-MUTAWASSIMĪN
}

\author{
Dhimas Muhammad Yasin ${ }^{1}$
}

\begin{abstract}
Abstrak: Naskah kuno merupakan salah satu bagian dari warisan leluhur yang wajib untuk dilestarikan dan dikaji. Selama ini keberadaan naskah kuno kurang diperhatikan dan banyak dari naskah kuno Indonesia berada di luar negeri. Preservasi naskah kuno menjadi hal yang penting untuk menjaga kedaulatan negara.Pelestarian dan pengkajian naskah kuno dapat dilakukan dengan berbagai cara, beberapa diantaranya adalah dengan digitalisasi dan deskripsi. Penelitian ini termasuk dalam penelitian kualitatif yang bersifat deskriptif. Sumber data yang digunakan adalah naskah Al-Mutawassimin. Naskah ini tersimpan di Perpustakaan Pusat Kegiatan Belajar Masyarakat (PKBM) Pinilih, Soditan, Desa Gumpang, Kecamatan Kartasura, Kabupaten Sukoharjo, Provinsi Jawa Tengah. Teknik pengumpulan data yang digunakan adalah teknik pustaka. Teknik analisis data yang digunakan adalah metode analisis isi berdasarkan kajian filologi. Teknik penarik simpulan yang digunakan adalah teknik induktif. Berdasarkan kajian terhadap naskah Al-Mutawassimin, dapat disimpulkan sebagai berikut. Pertama, digitalisasi naskah Al-Mutawassimin dinilai cukup efektif dan efisien sebagai upaya penyelamatan salah satu benda budaya Indonesia. Kedua, hasil deskripsi naskahAl-Mutawassimin memberikan gambaran terperinci seluk-beluk naskah tersebut, baik kondisi fisik atau ciri-ciri maupun keberadaan terkini naskah tersebut.
\end{abstract}

Kata Kunci:Al-Mutawassimin, digitalisasi, deskripsi, preservasi.

\section{PENDAHULUAN}

\subsection{Latar Belakang Masalah}

Bangsa Indonesia sebagai bangsa yang besar mempunyai kekayaan budaya yang sangat beraneka ragam, dari Sabang sampai Merauke. Sudjiman (1995) mengemukakan bahwa sebagian kebudayaan bangsa Indonesia pada masa lampau tergali dari peninggalan purbakala, termasuk prasasti dan naskah kuno yang ditulis tangan. Di dalam naskah kuno, terkandung suatu peristiwa dan unsur-unsur lain yang mengandung nilai-nilai luhur yang cukup penting pada masa lampau. Dari peninggalan-peninggalan tersebut dapat diketahui informasi tentang keberadaan dan kehidupan mereka.

Seiring berjalannya waktu, naskah-naskah kuno yang merupakan salah satu warisan

\footnotetext{
${ }^{1}$ Penulis: Dhimas Muhammad Yasin, Pemerhati pertahanan. Alumnus UniversitasSebelasMaret Surakarta dapat dihubungi didhimas060292@gmail.com
}

budaya Indonesia itu mengalir ke luara negeri tanpa alasan yang jelas. Baried dalam Mu'jizah (2013) mengemukakan bahwa sejak abad ke-18 hingga masa kini, naskah kuno sudah masuk dalam perdagangan gelap benda-benda antik. Beberapa kali dalam media massa diungkap masalah jualbelimanuskrip Indonesia di berbagai daerah di Indonesia, di antaranya:

Kompas:

"Sebanyak 83 naskah Jawa yang tersimpan di Inggris (75 dari British Library, 8 dari Royal AsiaticSociety dan juga John RylandsUniversityLibrary, Manchester), dimikrofilmkan dan menghasilkan 60 rol mikrofilm". (IND/DOE, 2013)

Republika:

"Perpustakaan Nasional (Perpusnas) menyebutkan bahwa ribuan naskah kuno Indonesia dikuasai oleh instansi pemerintahan maupun warga asing, sehingga Pemerintah Indonesia terus berupaya mengambil kembali naskah bernilai sejarah nusantara tinggi tersebut". (Putra, 2014) 
Benda langka dan kuno ini penting dan banyak menarik perhatian karena di dalamnya terdapat beragam informasi, pemikiran, dan pengetahuan lokal. Misalnya catatan harian para penguasa, surat-surat berharga, adat-istiadat, sejarah, keagamaan, astrologi, dan pengetahuan lainnya (Baried, dkk, 1994)

.Persebaran benda-benda budaya Indonesia di luar negeri yang tak bertanggung jawab inilah yang dapat menyebabkan semacam "klaim benda budaya" oleh orang-orang asing selaku kolektor benda-benda budaya tersebut. Mereka akan melakukan berbagai cara agar benda itu menjadi hak milik mereka sendiri, seperti penelitian, hak paten, pendirian museum khusus benda-benda tersebut, dan lain-lain. Oleh karena itu, Yamin (2015) mengemukakan bahwa sudah sepatutnya bangsa Indonesia bersatu untuk mengembalikan martabatnya sebagai bangsa yang besar dan berdaulat. Jangan sampai budaya tersebut berpindah tangan karena kurangnya perhatian pemerintah untuk mematenkan budaya tersebut dalam aset negara yang tidak ternilai harganya.

Meskipun begitu, pemerintah Indonesia telah berusaha melakukan segala macam upaya untuk mempertahankan budaya luhur bangsa dari pengaruh negatif budaya luar. Salah satu upaya nyata yang ditempuh adalah dengan menggali kembali puncak-puncak kebudayaan daerah yang mengandung nilainilai luhur (Fakihuddin, 2014). Misalnya berbagai koleksi naskah kuno yang tersimpan di Museum Radya Pustaka Surakarta, Perpustakaan Nasional Republik Indonesia, Museum Ali Hasjmy Banda Aceh, dan museum atau perpustakaan lainnya.

Dalam Undang-Undang Dasar Republik Indonesia Tahun 1945 Amandemen Pasal 32 Ayat 1 dikemukakan sebagai berikut. "Negara memajukan kebudayaan nasional Indonesia di tengah peradaban dunia dengan menjamin kebebasan masyarakat dalam memelihara dan mengembangkan nilai-nilai budayanya". Oleh karena itu, peran pemerintah juga harus didukung oleh masyarakat, khususnya para filolog Indonesia selaku pemerhati ilmu kebudayaan dalam naskah kuno sebagai upaya pemeliharaan dan pengembangan nilai-nilai budaya dalam naskah tersebut.
Sehubungan dengan itu, berbagai upaya pemeliharaan naskah kuno telah dilakukan oleh para filolog atau pemerhati kebudayaan berdasarkan naskah kuno. Wirajaya (2010) mengemukakan bahwa pemeliharaan naskah itu antara lain: mengatur suhu udara tempat naskah itu disimpan sehingga tidak cepat lapuk; melapisi kertas-kertas yang sudah lapuk dengan kertas yang khusus untuk itu sehingga kuat kembali; dan menyemprot naskah-naskah itu dalam jangka waktu tertentu dengan bahan kimia yang dapat mengawetkan dan membunuh kutu-kutu yang memakan kertas itu.

Namun, berbagai penanganan naskah kuno seperti itu membutuhkan tingkat keuletan yang sangat tinggi. Jika petugas naskah lalai sedikit saja, maka naskah malah menjadi rusak akibat penanganan itu sendiri, baik secara sengaja maupun tidak. Selain itu, dibutuhkan biaya yang cukup banyak untuk melakukan itu semua. Bermula dari biaya membeli bahan kimia, membeli kertas lapisan khusus, biaya pembelian dan perawatan lemari atau tempat khusus penyimpanan naskah kuno, sampai membayar biaya operasional atau tenaga ahli yang bertugas menangani hal itu semua.

Seiring dengan perkembangan zaman, hadirlah sebuah inovasi teknologi yang disebut dengan digitalisasi, seperti komputer atau proyektor, scanner atau fotokopi, kamera digital atau camcorder, dan sebagainya. Dengan hadirnya digitalisasi yang makin canggih dari masa ke masa, proses penanganan naskah kuno menjadi lebih mudah. Kumpulan foto digital dapat disimpan ke dalam komputer atau ke dalam email yang memungkinkan penyimpanan data dalam jumlah yang besar dan dalam jangka waktu yang cukup lama.

Dalam Undang-Undang Republik Indonesia Nomor 11 Tahun 2010 Tentang Cagar Budaya dikemukakan bahwa kriteria benda, bangunan, atau struktur yang dapat diusulkan sebagai benda cagar budaya, bangunan cagar budaya, atau struktur cagar budaya adalah sebagai berikut.

a. berusia 50 (lima puluh) tahun atau lebih;

b. mewakili masa gaya paling singkat berusia 50 (lima puluh) tahun; 
c. memiliki arti khusus bagi sejarah, ilmu pengetahuan, pendidikan, agama, dan/atau kebudayaan; dan

d. memiliki nilai budaya bagi penguatan kepribadian bangsa.

Al-Mutawassimin merupakan teks Melayu dalam naskah Melayu, yang menurut kolofon teksnya berarti 'orang-orang yang mengenal akan tanda-tanda kebesaran Allah'. AlMutawassimin tersimpan di Perpustakaan Pusat Kegiatan Belajar Masyarakat (PKBM) Pinilih, Soditan, Gumpang, Kartasura, Sukoharjo, Jawa Tengah. Al-Mutawassimin tersajikan dengan genre sastra kitab yang membahas ajaran tauhid dalam Islam. AlMutawassimin merupakan naskah tulisan tangan/manuskrip dengan huruf Arab Melayu dan huruf pegon, berbahasa Melayu dan Jawa, dan disisipi kata-kata dari bahasa Arab. Kertas yang digunakan adalah kertas merang atau kertas yang terbuat dari tangkai padi yang sudah kering. Tinta yang digunakan adalah tinta bak berwarna hitam dan merah. Teks Al-Mutawassimin ditulis pada tahun 1908.

Berdasarkan latar belakang di atas, maka diperlukan penelitian Al-Mutawassimin. Langkah-langkah kerja dalam penelitian ini yaitu dengan melakukan digitalisasi terhadap naskah tersebut, lalu menyajikannya dalam bentuk suntingan yang baik dan benar, kemudian melakukan deskripsi naskah. Dari kajian tersebut, dapat diketahui seluk-beluk naskah, tulisan naskah, dan bahasa naskah dalam teks Al-Mutawassimin.

\subsection{Rumusan Masalah}

Berdasarkan latar belakang yang telah dikemukakan sebelumnya, dapat dirumuskan permasalahan sebagai berikut. "Bagaimana digitalisasi naskah Al-Mutawassimin dan deskripsi naskah Al-Mutawassimin?"

\subsection{Tujuan Penelitian}

Berdasarkan rumusan masalah yang telah dikemukakan sebelumnya, penelitian ini bertujuan untuk menyajikan digitalisasi naskah Al-Mutawassimin dan menyajikan deskripsi naskah Al-Mutawassiminn.

\subsection{Manfaat Penelitian}

Penelitian ini diharapkan dapat menyebarluaskan Al-Mutawassimin sebagai salah satu karya sastra Melayu klasik bergenre sastra kitab di Nusantara dan membantu melestarikan salah satu benda budaya peninggalan nenek moyang bangsa Indonesia. Dengan demikian, naskah yang sudah terdigitalisasi dan terdeskripsi oleh orang Indonesia itu sendiri tidak begitu saja berpindah tangan ke luar negeri sehingga tidak akan muncul "klaim benda budaya" oleh bangsa lain. Jika kebudayaan Indonesia terus dipertahankan keasliannya, maka kedaulatan Indonesia sebagai bangsa yang besar karena kebudayaannya pun juga akan terus kokoh.

\subsection{Metode Penelitian}

Penelitian ini termasuk dalam penelitian kualitatif yang bersifat deskriptif. Sumber data yang digunakan adalah naskah AlMutawassimin. Naskah ini tersimpan di Perpustakaan Pusat Kegiatan Belajar Masyarakat (PKBM) Pinilih, Soditan, Gumpang, Kartasura, Sukoharjo. Teknik pengumpulan data yang digunakan adalah teknik pustaka. Teknik analisis data yang digunakan adalah metode penyuntingan teks. Metode penyuntingan teks yang digunakan adalah metode standar. Teknik penarik simpulan yang digunakan adalah teknik induktif.

\subsection{Landasan Teori}

Dalam filologi dikenal istilah "digitalisasi". Digitalisasi naskah merupakan suatu upaya penyelamatan naskah-naskah kuno dengan memanfaatkan teknologi digital. Misalnya softfile, foto digital, dan mikrofilm. Tujuannya untuk mengupayakan naskah asli atau naskah duplikatnya dapat bertahan selama mungkin (Sakamoto dalam Wirajaya, 2010).

Dalam digitalisasi perlu data sebagai objeknya yaitu naskah. Oleh karena itu, pencarian dan pengumpulan informasi terkait keberadaan naskah itu sangat diperlukan. Dalam filologi, cara-cara pengumpulan naskah, meliputi: studi lapangan, studi katalog, dan kumpulan artikel tentang naskah.

Studi lapangan dilakukan dengan terjun ke lingkungan masyarakat dan mendatangi orang-orang tertentu atau tempat-tempat tertentu yang diduga menyimpan koleksi naskah, seperti masjid, pondok pesantren, toko buku kuno, museum, perpustakaan, dan sebagainya (Sudardi, 2003). 
Studi katalog dilakukan dengan mendaftar judul naskah yang akan diteliti melalui katalog naskah atau melakukan pencarian informasi tentang naskah yang diperoleh melalui katalog naskah. Naskah yang terdaftar di katalog biasanya dimiliki oleh museum, perpustakaan, atau instansi yang mengoleksi naskah (Sudardi, 2003).

Dalam kumpulan artikel tentang naskah, biasanya terdapat berbagai informasi adanya penemuan naskah-naskah baru yang tidak terdapat pada beberapa katalog. Selain itu, kumpulan artikel tentang naskah juga menyajikan hal-hal aktual mengenai naskah dam mengoreksi beberapa kekeliruan atau kekurangan deskripsi naskah dalam suaatu katalog naskah (Sudardi, 2003)

Dalam filologi juga dikenal istilah "kodikologi". Kodikologi berasal dari kata Latin: codex (bentuk tunggal; bentuk jamak ialah codices) yang di dalam bahasa Indonesia diterjemahkan menjadi naskah, bukan menjadi kodeks (Mulyadi, 1994). Selain itu, Baried, dkk (1994) menambahkan bahwa kodikologi ialah ilmu kodeks yang berarti ilmu yang mempelajari bahan (naskah kuno) yang berupa tulisan tangan.

Dalam penelitian kodikologi juga dikenal istilah "deskripsi". Deskripsi naskah adalah memaparkan informasi mengenai seluk-beluk naskah yang menjadi objek penelitian. Deskripsi naskah Al-Mutawassimin dilakukan dengan menguraikan secara terperinci keadaan naskah yang akan diteliti. Semua naskah dideskripsikan dengan pola yang sama, meliputi: judul naskah, nomor naskah, tempat penyimpanan naskah, asal naskah, keadaan, ukuran naskah, tebal naskah, jumlah baris pada setiap halaman naskah, bentuk huruf, cara penulisan, bahan naskah, bahasa naskah, bentuk teks, umur naskah, identitas pengarang teks, fungsi teks, dan ikhtisar isi teks (Saputra, 2008).

\section{ISI PENELITIAN}

Beberapa tahapan digitalisasi dan deskripsi naskahAl-Mutawassimin diuraikan sebagai berikut.

\subsection{Pencarian Informasi Naskah}

Tahap awal yang dilakukan dalam pengumpulan data ialah pencarian informasi terhadap naskah yang akan dijadikan sumber data penelitian. Pencarian informasi dilakukan melalui inventarisasi naskah berupa studi lapangan dan studi katalog. Studi lapangan dilakukan dengan mendatangi langsung Perpustakaan Pusat Kegiatan Belajar Masyarakat (PKBM) Pinilih, Soditan RT.1/RW.3 Gumpang, Kartasura, Sukoharjo, Jawa Tengah. Studi lapangan dilakukan berdasarkan keterangan dari salah satu pengurus perpustakaan tersebut yang bernama Mulyono, S.Pd.. Dari keterangan tersebut, diketahui bahwa naskah A/Mutawassimin belum pernah dilakukan penelitian, baik dari segi digitalisasi maupun deskripsi. Lalu dari tempat tersebut ditemukan naskah Al-Mutawassiminn dengan nomor buku 900.331 .

Wirajaya (2010) mengemukakan bahwa adapun spesifikasi kamera otofokus digital untuk sebuah digitalisasi naskah yaitu sebagai berikut. "DSLR/Digital SingleLensReflex, min 5,1 MP, format RAW (format foto 'mentah' yang dapat menyerap semua karakter objek foto, seperti warna, cahaya, dan lain sebagainya), memiliki fitur RemoteLiveViewShooting sehingga memudahkan proses pengambilan gambar dari PC atau laptop." Pada penelitian kali ini, penulis menggunakan kamera digital autofocus NIKON COOLPIX AW110 16 MP.

\subsection{Digitalisasi Naskah}

Pemerolehan data dilakukan dengan cara memotret naskah setiap jepretan pada setiap halamannya dengan kamera otofokus digital tanpa menggunakan blitz (lampu kilat). Hal ini bertujuan agar naskah tidak rusak akibat panas cahaya yang ditimbulkan dari lampu kilat kamera otofokus digital tersebut. Selain itu, lampu kilat dapat menyebabkan hasil foto malah menjadi silau sehingga tampak kurang jelas atau tidak maksimal.

Setelah dilakukan digitalisasi, langkah berikutnya yaitu melakukan studi katalog untuk naskah yang akan diteliti merupakan naskah tunggal atau naskah jamak. Studi katalog dilakukan dengan mengumpulkan informasi naskah yang akan diteliti melalui katalog-katalog naskah. Katalog yang digunakan adalah katalog terbitan yang menyajikan informasi keberadaan naskahnaskah Melayu. Berikut katalog-katalog terbitan yang digunakan dalam penelitian AIMutawassimin ini. 
1. MalayManuscripts: BibliograpicalGuide(Howard, 1966),

2. Katalogus Koleksi Naskah Melayu Museum Pusat(Sutaarga, et.al., 1972),

3. Katalog Induk Naskah-Naskah Nusantara Jilid 4(Behrend, 1998),

4. Katalog Induk Naskah-Naskah Nusantara Jilid 5A: Jawa Barat; Koleksi Lima Lembaga (Ekadjati dan Undang A. Darsa, 1999),

5. Katalog Naskah Buton: Koleksi Abdul MulkuZahari(lkram, et. al, 2001),

6. Katalog Naskah Merapi-Merbabu (Setyawati, I. KuntaraWiryamartana, dan Willem Van derMollen, 2002),

7. Katalog Naskah Palembang (Ikram, 2004),

8. Katalog Naskah Bima: Koleksi Museum Kebudayaan Samparaja (Maryam, Salahuddin dan Mukhlis, 2007),

9. Katalog Naskah Ali Hashmy Aceh, Catalog of Aceh Manuscripts: Ali HashmyColllection (Fathurahman dan Munawar Holil, 2007),

10. Katalog Naskah DayahTanohAbee Aceh Besar (Fathurahman, 2010).

Selain itu, pencarian informasi juga dilakukan pada beberapa universitas, perpustakaan atau instansi terkait yang dimungkinkan adanya penelitian atau kumpulan artikel tentang naskah, seperti Universitas Gadjah Mada (UGM), Universitas Indonesia (UI), Universitas Sebelas Maret Surakarta (UNS), Perpustakaan Nasional Republik Indonesia (PNRI) dan Badan Pengembangan dan Pembinaan Bahasa Jakarta. Pencarian informasi-informasi pada beberapa instansi tersebut dilakukan secara online.

Berdasarkan studi atau pencarian informasi tersebut, tidak ditemukan naskah yang identik atau berjudul sama dengan Al-Mutawassiminn. Oleh karena itu, Al-Mutawassimīn dianggap naskah tunggal atau naskah satu-satunya (codexunicus).

\subsection{Percetakan Naskah}

Tahap berikutnya setelah pencarian informasi ialah pencetakan naskah.Tahap pencetakan naskah dilakukan dengan cara semua data yang diperoleh berupa foto naskah ditransfer ke dalam komputer. Data kemudian diproses dan di-print-out untuk memperoleh data sesuai dengan wujud gambaran asli naskah. Selain itu, naskah yang telah di-print-out juga mempermudah penulis dalam mengkaji naskah terutama dalam melakukan deskrpsi naskah.

\subsection{Deskripsi Naskah}

Tahap berikutnya setelah pencetakan data ialah melakukan deskripsi yang berupa naskah. Deskripsi naskah berfungsi sebagai sumber penyajian informasi tertulis mengenai seluk-beluk naskah dan sebagai patokan kelayakan dari naskah yang akan diteliti. Deskripsi naskah dilakukan dengan memaparkan seluk-beluk naskah secara terperinci atau panjang lebar. Dari deskripsi naskah, dapat diketahui data dianalisis berdasarkan masalah-masalah yang diangkat dalam penelitian.

Judul naskah setelah dilakukan deskripsi naskah adalah Al-Mutawassimin, yang berarti 'orang-orang yang mengenal akan tandatanda kebesaran Allah'. Naskah AlMutawassimin memiliki nomor buku 900.331 Naskah Al-Mutawassimin tersimpan di Perpustakaan Pusat Kegiatan Belajar Masyarakat (PKBM) Pinilih, Soditan RT. 01/RW. 03 Gumpang, Kartasura, Sukoharjo, Jawa Tengah.Kondisi fisik naskahAlMutawassimin masih utuh, meskipun bagian bawah seluruh halaman naskah terdapat sobekan kecil. Sampul naskah berwarna cokelat tua dan dijilid sendiri oleh pemiliknya. Tulisan masih lengkap, terbaca jelas, dan ditulis dengan tinta warna hitam dan tinta warna merah.

Lembaran naskah Al-Mutawassimīn berukuran $21,5 \mathrm{~cm} \times 16 \mathrm{~cm}$. Ruang teks $A /$ Mutawassimin berukuran $19,5 \mathrm{~cm} \times 13,5 \mathrm{~cm}$. Sampul naskah Al-Mutawassimin berukuran $21,5 \mathrm{~cm} \times 16,5 \mathrm{~cm}$. Tebal naskahAlMutawassimin seluruhnya 20 halaman atau 3 kuras, yang terdiri atas 2 halaman sampul depan, 1 halaman kosong, 15 halaman teks, dan 2 halaman sampul belakang. Halaman 1 kosong, halaman 2-13 terdiri atas 13 baris, halaman 14 terdiri atas 12 baris, dan halaman 15 terdiri atas 8 baris.

Bahasa yang digunakan dalam teks AlMutawassimin adalah bahasa Melayu dan terdapat beberapa pengaruh dari bahasa Jawa. Selain itu, Al-Mutawassimin juga mengggunakan beberapa istilah bahasa 
Arab. Jenis tulisan yang dipakai dalam AlMutawassiminadalah jenis tulisan tangan atau khatyang sangat kaku dengan sedikit putaran dan banyak memiliki sudut yang tajam. Ukuran huruf yang dipakai $A /$ Mutawassimīnberukuran sama besar. Bentuk huruf yang dipakai dalam teks AlMutawassiminberbentuk tegak lurus dan kaku (perpendicular).

Keadaan tulisan dalam teks A/Mutawassimincukup baik, mudah dibaca, rapi, dan bentuk tulisannya konsisten atau tidak berubah-ubah dari awal sampai akhir teks. Jarak antarhuruf dalam teks AlMutawassimintermasuk renggang atau tidak rapat dan jarak antarbaris teratur sehingga tulisan terlihat rapi. Goresan pena dalam teksAl-Mutawassiminnditulis dengan tingkat ketebalan besar, tetapi tidak sampai menembus halaman sebaliknya. Warna tinta yang dipakai dalam teks Al-Mutawassiminada dua macam, yaitu tinta merah dan tinta hitam. Dalam teks Al-Mutawassiminterdapat katakata tumpuan yang berfungsi sebagai pembatas antarkalimat atau antaralinea: adapun, bermula, dan, atau maka.

Cara penempatan tulisan pada lembar naskah Al-Mutawassiminyaitu teks ditulis dari arah kanan ke kiri, seperti penulisan huruf Arab. Ruang tulisan dalam A/Mutawassiminterbentuk secara bebas, tidak ada pembatas atau garis yang mengatur ruang tulisan. Tidak ada nomor halaman pada Al-Mutawassimin, baik penomoran angka maupun penomoran catchword.

Bahan naskah Al-Mutawassiminadalah kertas merang. Kertas merang adalah kertas yang terbuat dari jerami atau bekas tangkai padi yang sudah kering. Kertas ini berwarna kuning kecokelatan. Kertas agak tipis dan sedikit rapuh. Sampul naskah menggunakan kertas karton tipis berwarna cokelat tua. Bentuk teks yang digunakan AlMutawassiminadalah bentuk prosa.

Berdasarkan keterangan pada halaman akhir teks Al-Mutawassimindisebutkan tahun 1908. Jika dihitung dari tahun sekarang (2016), maka naskahAl-Mutawassimin berusia 108 tahun. Naskah tersebut tersimpan di Perpustakaan Pusat Kegiatan Belajar Masyarakat (PKBM) Pinilih, Soditan RT.
01/RW. 03 Gumpang, Kartasura, Sukoharjo, Jawa Tengah sejak tahun 2010 dan dirawat oleh Mulyono, S.Pd., selaku pengurus perpustakaan.

Al-Mutawassimin tergolong sastra kitab. Sastra kitab termasuk salah satu genre dalam karya sastra. Karya sastra merupakan salah satu objek penelitian yang layak untuk diteliti karena karya sastra memiliki fungsifungsi yang penting dalam kehidupan masyarakat. Fungsi-fungsi karya sastra, meliputi: fungsi karya sastra sebagai seni, fungsi magi, fungsi pendidikan dan fungsi hiburan (Soeratno, 1982).

Al-Mutawassimin merupakan karya sastra yang di dalamnya berisi ajaran agama Islam, khususnya ajaran tauhid. Jadi, AlMutawassimin memiliki fungsi magi, fungsi pendidikan, dan fungsi hiburan karena berhubungan dengan fungsi dan peranan akidah (tauhid), meliputi: (1) menuntun dan mengembangkan dasar ketuhanan yang dimiliki manusia sejak lahir; (2) memberikan ketenangan dan memberikan ketenteraman jiwa; (3) memberikan pedoman hidup yang pasti (Taufiq dan Rohmadi, 2010).



Gambar 1. Lembar pertama naskah Al-Mutawassimin 


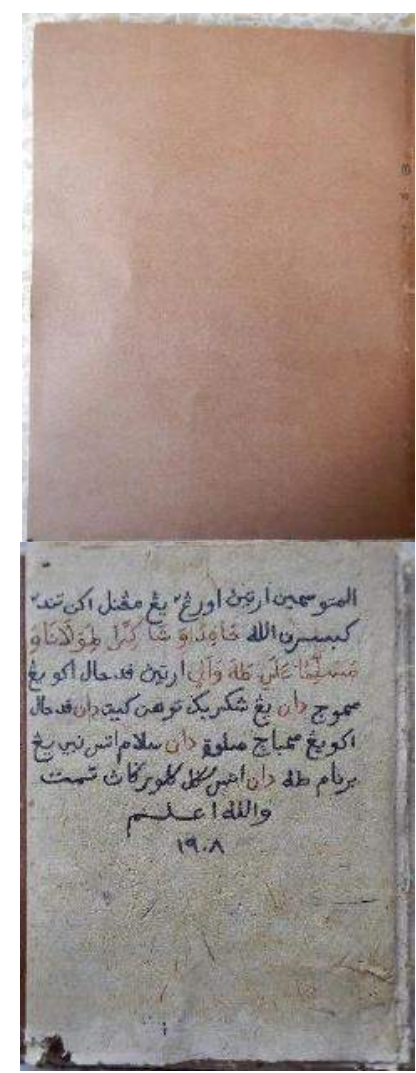

Gambar 2. Lembar akhir naskah

Gambar 2. Lembar akhir naskah AlMutawassimin

\section{Ikhtisar Isi Teks Al-Mutawassimīn}

\section{Halaman 1-6}

1. Pendahuluan, terdiri atas:

- basmallah dalam bahasa Arab diikuti terjemahan dalam bahasa Melayu;

- penjelasan makna Rahman dan Rahim;

- penjelasan makna Rahman dan Rahim secara umum dan khusus;

- permulaan teks dengan bismillah dan alhamdulillah didukung dalilnya;

- selawat dan salam kepada Nabi Muhammad SAW. dalam bahasa Arab diikuti terjemahan dalam bahasa Melayu;

- salam kepada keluarga, sahabat, dan pengikut Nabi Muhammad SAW. dalam bahasa Arab diikuti terjemahan dalam bahasa Melayu;

- penjelasan tentang makna dari bacaan alhamdulillah;

- penjelasan tentang makna selawat kepada Nabi Muhammad SAW.;

- definisi sahabat nabi
- kata "wabakdu", yang artinya 'dan adapun kemudian daripada itu';

- alasan atau latar belakang penulisan teks dalam bahasa Arab diikuti terjemahan dalam bahasa Melayu.

Halaman 7-14

2. Isi, terdiri atas:

- definisi sifat wajib Allah yang pertama, sifat mustahil Allah yang pertama, dan penggolongan sifat wajib Allah yang pertama;

- definisi sifat wajib Allah yang kedua, sifat mustahil Allah yang kedua, dan penggolongan sifat wajib Allah yang kedua;

- definisi sifat wajib Allah yang ketiga, sifat mustahil Allah yang ketiga, dan penggolongan sifat wajib Allah yang ketiga;

- definisi sifat wajib Allah yang keempat, sifat mustahil Allah yang keempat, dan penggolongan sifat wajib Allah yang keempat;

- definisi sifat wajib Allah yang kelima, sifat mustahil Allah yang kelima, dan penggolongan sifat wajib Allah yang kelima;

- definisi sifat wajib Allah yang keenam, sifat mustahil Allah yang keenam, dan penggolongan sifat wajib Allah yang keenam;

- definisi sifat wajib Allah yang ketujuh, sifat mustahil Allah yang ketujuh, dan penggolongan sifat wajib Allah yang ketujuh;

- definisi sifat wajib Allah yang kedelapan, sifat mustahil Allah yang kedelapan, dan penggolongan sifat wajib Allah yang kedelapan;

- definisi sifat wajib Allah yang kesembilan, sifat mustahil Allah yang kesembilan, dan penggolongan sifat wajib Allah yang kesembilan;

- definisi sifat wajib Allah yang kesepuluh, sifat mustahil Allah yang kesepuluh, dan penggolongan sifat wajib Allah yang kesepuluh;

- definisi sifat wajib Allah yang kesebelas, sifat mustahil Allah yang kesebelas, dan penggolongan sifat wajib Allah yang kesebelas;

- definisi sifat wajib Allah yang kedua belas, sifat mustahil Allah yang kedua belas, dan penggolongan sifat wajib Allah yang kedua belas; 
- definisi sifat wajib Allah yang ketiga belas, sifat mustahil Allah yang ketiga belas, dan penggolongan sifat wajib Allah yang ketiga belas;

- definisi sifat wajib Allah yang keempat belas, sifat mustahil Allah yang keempat belas, dan penggolongan sifat wajib Allah yang keempat belas; definisi sifat wajib Allah yang kelima belas, sifat mustahil Allah yang kelima belas, dan penggolongan sifat wajib Allah yang kelima belas;

- definisi sifat wajib Allah yang keenam belas, sifat mustahil Allah yang keenam belas, dan penggolongan sifat wajib Allah yang keenam belas;

definisi sifat wajib Allah yang ketujuh belas, sifat mustahil Allah ketujuh belas, dan penggolongan sifat wajib Allah yang ketujuh belas;

- definisi sifat wajib Allah yang kedelapan belas, sifat mustahil Allah yang kedelapan belas, dan penggolongan sifat wajib Allah yang kedelapan belas;

- definisi sifat wajib Allah yang kesembilan belas, sifat mustahil Allah yang kesembilan belas, dan penggolongan sifat wajib Allah yang kesembilan belas;

- definisi sifat wajib Allah yang kedua puluh, sifat mustahil Allah yang kedua puluh, dan penggolongan sifat wajib Allah yang kedua puluh.

Halaman 14-15

3. Penutup, terdiri atas:

- penjelasan akhir teks dan ungkapan penulis diberi kemudahan dalam bahasa Arab diikuti terjemahan dalam bahasa Melayu;

- judul karangan atau teks beserta artinya;

- doa penutup berupa syukur dan selawat kepada Nabi Muhammad SAW. dan keluarganya dalam bahasa Arab diikuti terjemahan dalam bahasa Melayu; kata "tamat";

- waktu selesai penyalinan.

\section{PENUTUP}

\subsection{Kesimpulan}

Berdasarkan isi penelitian di atas, dapat disimpulkan sebagai berikut. Pertama, digitalisasi naskah Al-Mutawassimin dinilai cukup efektif dan efisien sebagai upaya penyelamatan salah satu benda budaya
Indonesia. Digitalisasi bertujuan agar naskah asli atau naskah duplikatnya dapat bertahan selama mungkin. Efektif dalam arti berhasil atau berpengaruh besar. Efisien dalam arti tidak membuang-buang waktu, tenaga, dan biaya terlalu banyak.

Kedua, hasil deskripsi naskahAlMutawassimin memberikan gambaran secara terperinci seluk-beluk naskah tersebut, baik kondisi atau ciri-ciri fisik maupun keberadaan terkini naskah tersebut. Selain itu, teks AlMutawassimin bergenre sastra kitab dan terkandung ajaran tauhid yang dapat dijadikan referensi bagi umat Islam dalam memahami atau melaksanakan setiap ajaran agama Islam.

\subsection{Saran}

Dengan adanya digitalisasi dan deskripsi naskah Al-Mutawassimin, diharapkan dapat menjadi perhatian atau menggugah semangat bagi seluruh masyarakat Indonesia, khususnya kepada para pemilik naskah kuno. Memang penelitian ini masih terdapat beberapa kekurangan bila dibandingkan dengan penelitian filologi lainnya dikarenakan keterbatasan penulis dalam memperoleh referensi dan menguasai teknologi. Namun, setidaknya penulis sudah berusaha untuk memberikan sedikit kontribusi atau peran dalam upaya mempertahankan kedaulatan Republik Indonesia. Sebagai bangsa yang besar akan kebudayaannya, tentu kita tidak rela begitu saja hasil kebudayaan nenek moyang kita hilang atau diberikan begitu saja kepada orang-orang asing. Jika masyarakat bangsa kita selalu mengapresiasi atau melestarikan hasil-hasil kebudayaannya, maka kedaulatan bangsa Indonesia juga akan terus kokoh sehingga kita dihormati oleh bangsa atau negara lain.

\section{DAFTAR PUSTAKA}

Baried, Siti Baroroh, dkk. 1994. Pengantar Teori Filologi. Yogyakarta. Badan Penelitian dan Publikasi Fakultas (BPPF) Fakultas Sastra UGM.

Behrend, T. E. (Ed.). 1998. Katalog Induk Naskah-Naskah Nusantara Jilid 4 Perpustakaan Nasional Republik Indonesia. Jakarta: Yayasan Obor Indonesia dan EcoleFrancaise D"ExtremeOrient. 
Ekadjati, Edi S.. 1999. Katalog Induk NaskahNaskah Nusantara Jilid 5A: Jawa Barat; Koleksi Lima Lembaga. Jakarta: Manassa dan Yayasan Obor Indonesia.

Fakihuddin, Lalu. 2014. Mengungkap Sifatsifat Terpuji Manusia dalam Cerita Rakyat Sasak: Suatu Kajian Tematis. Lingua: Jurnal Bahasa, Sastra, dan Pengajarannya $11 \quad$ (1): 45-55. [Internet]. Tersedia pada: http://www.jurnallingua.info/downloads/5LALU\%20FAKIHUDINSASTRA\%20SASAK.pdf[Diakses pada 6 Agustus 2016].

Fathurahman, Oman. 2010. Katalog Naskah DayahTanohAbee Aceh Besar. Jakarta: Komunitas Bambu.

Fathurahman, Oman dan Munawar Holil. 2007. Katalog Naskah Ali Hashmy Aceh. Tokyo University of ForeignStudies (TUFS) bekerja sama dengan Area-TransculturalStudies (CDATS).

Howard, Joseph H. 1966. MalayManuscripts: A Bibliograpicalguide. Kuala Lumpur.

Ikram, Achadiati. 2004. Katalog Naskah Palembang. Jakarta: Yayasan Naskah Nusantara (Yanassa) bekerja sama dengan Tokyo University of ForeignStudies (TUFS).

Ikram, Achadiati, et.al. 2001. Katalog Naskah Buton: Koleksi Abdul MulkuZahari. Jakarta: Yayasan Obor Indonesia.

Kompas.com. 2013. Naskah Kuno Indonesia Terus Mengalir ke Luar Negeri. [Internet]. Tersedia pada: http://sains.kompas.com/read/2013/07/ 15/1712232/Naskah.Kuno.Indonesia.Te rus.Mengalir.ke.Luar.Negeri[Diakses pada 17 September 2016].

Maryam, Siti., R. Salahuddin, dan Mukhlis. 2007. Katalog Naskah Bima Koleksi Museum Kebudayaan Samparaja. Bima: Museum Samparaja.

Mu'jizah. 2013. Manuskrip Indonesia sebagai Pustaka Dunia: Persebaran dan Apresiasi. Makalah dalam Kongres Bahasa Indonesia X. [Internet]. Tersedia pada:http://badanbahasa.kemdikbud.go .id/lamanbahasa/sites/default/files/Kum pulan\%20Makalah\%20KBI\%20X subte ma\%206-rev.pdf[Diakses pada 6 Agustus 2016].
Mulyati, Sri Wulan Rujiati. 1994. Kodikologi Melayu di Indonesia. Depok. Badan Penerbit Fakultas Sastra UI.

Republika.co.id.2014. Ribuan Naskah Kuno Indonesia Dikuasai Asing. [Internet]. Tersedia pada: http://nasional.republika.co.id/berita/nas ional/jabodetabeknasional/14/10/25/ndzcct-ribuannaskah-kuno-indonesia-dikuasaiasing[Diakses pada 17 September 2016].

Saputra, Karsono H. 2008. Pengantar Filologi Jawa. Jakarta: Wedhatama Widya Sastra.

Setyawati, Kartika., I. KuntaraWiryamartana, dan Willem vanderMolen. 2002. Katalog Naskah Merapi-Merbabu: Perpustakaan Nasional Republik Indonesia. Yogyakarta: Universitas Sanata Dharma Press.

Soeratno, Siti Chamamah. 1982. Memahami Karya-karya NuruddinAr-Raniri. Yogyakarta: UGM Press.

Sudardi, Bani. 2003. Penggarapan Naskah. Surakarta: Badan Penerbit Sastra Indonesia (BPSI).

Sudjiman, Panuti. 1995. Filologi Melayu: Kumpulan Karangan. Jakarta: Pustaka Jaya.

Sutaarga, Amir, et.al. 1972. Katalogus Koleksi Naskah Melayu Museum Pusat Dep. $P$ dan K. Jakarta: Departemen Pendidikan dan Kebudayaan.

Taufiq, Ahmad dan Muhammad Rohmadi. 2010. Pendidikan Agama Islam: Pendidikan Karakter Berbasis Agama. Surakarta: Yuma Pustaka.

Undang-Undang Dasar Republik Indonesia Tahun 1945 Amandemen. Jakarta.

Undang-Undang Republik Indonesia Nomor 11 Tahun 2010 Tentang Cagar Budaya. Lembaran Negara Republik Indonesia Tahun 2010 Nomor 130. Jakarta.

Wirajaya, Asep Yudha. 2010. Upaya Pelestarian Naskah-Naskah Melalui Teknologi Digital. Makalah disajikan pada Kuliah Perdana dan Kuliah Umum Sivitas Akademika Jurusan Sastra Indonesia, 10 November 2010. Surakarta: Universitas Sebelas Maret.

Yamin. 2015. Pancang Ideologi di Tapal Batas Republik Indonesia dan Malaysia. Kumpulan Makalah Call For Papers Kongres Pancasila VII (hal.93-104). [e-book]. Yogyakarta: Pusat Studi Pancasila Universitas Gadjah Mada. Tersedia pada: 
GoogleBookshttps://books.google.co.id/books

?id=N8ClCwAAQBAJ\&pg=PA93\&dq=pancan

g+ideologi+di+tapal+batas+republik+indonesi $\underline{a+d a n+\text { malaysia\&hl=id\&sa }=X \& \text { ved }=0 \text { ahUKE }}$ wiuh9vfgP3PAhUVS48KHY9iCWgQ6AEIHD AA\#v=onepage \&q=pancang $\% 20$ ideologi $\% 20$ di\%20tapal\%20batas\%20republik\%20indone sia\%20dan\%20malaysia\&f=false [Diakses pada 28 Oktober 2016]. 